\title{
FEATURES OF THE CLINICAL PICTURE OF DEPRESSIVE DISORDERS OF DIFFERENT REGISTERS IN UNIVERSITY STUDENTS
}

\author{
Vashkite I., Khaustov M. \\ Kharkiv National Medical University, Ukraine \\ https://doi.org/10.35339/ic.6.2.112-119
}

\begin{abstract}
In the course of work with the purpose of developing a complex pathopsychologically grounded system of psychotherapy and psychoprophylaxis for students of higher educational institutions with depressive disorders of affective (DDAR) and neurotic (DDNR) registers, a complex psychodiagnostic, psychometric, and clinical and psychopathological study of 200 students from various universities at the age of 17-24 was conducted.

According to the results of the study, it was revealed that the effect of factors related to the start of studies at the university results in the highest probability of depressive disorders of the neurotic register among younger students. Students of senior years are maximally adapted to the conditions of study; therefore, the incidence of these disorders, both clinical and subclinical, is average among them, whereas in senior years there is an increase in the incidence of depressive disorders of the affective register.

The article also presents the diagnostic results of studying the emotional sphere of students, the syndromological structure of depressive disorders of both registers, and formulated recommendations on the diagnosis and treatment of patients with depressions in the primary medical system.
\end{abstract}

Keywords: depressive reactions, diagnosis, primary care, students, treatment.

\section{Introduction}

Today's world has a tendency for acceleration of the pace of life, an increase in the number of communication links, intensification of social and economic tensions in society and urbanization. This leads to an increase in the prevalence of mental and psychosomatic diseases, above all borderline, neurotic level, putting forward the task of their early diagnosis, correction and prevention as a priority [1-3].

At the present stage of development of society general medical problems including the affective conditions, especially anxiety and depressive disorders, are particularly pressing. According to the WHO, currently more than 110 million people in the world $-3-6 \%$ of the population - have

\section{Corresponding Author:}

Inna Vashkite $\mathrm{MD}, \mathrm{PhD}$ professor assistant of the Department of Department of Psychiatry, Narcology and Medical Psychology

of Kharkiv National Medical University, Ukraine. E-mail: vashkiteinna@yahoo.com clinically significant manifestations of these disorders. A similar trend is observed in Ukraine [4-7].

The growing urgency of the problem of depression is due to their incidence, the significant influence of the disease on the quality of life and social functioning of a person, as well as the largest level of suicides among mental disorders $[4,8,9]$. All this leads to social disadvantages and economic losses $[10,11]$.

At the same time, the growth of depressive disorders does not occur due to endogenous forms, but due to psychogenic, reactive, mixed forms, which are called masked forms, somatogenic and which are manifested above all, as somatovegetative disorders.

According to the World Health Organization (WHO), by the beginning of the $21^{\text {st }}$ century, the proportion of depression and anxiety disorders was about $40 \%$ in the overall structure of mental illness, which is registered in the world. Every year about 200 million people in the world suffer from clinically diagnosed depression and this 
figure is steadily increasing. Every eighth person needs specialized antidepressant therapy at least once in his life $[4,12,13,5]$.

Particularly relevant, this problem occurs in relation to persons who are in conditions of prolonged or intense information stress, in particular, students of higher educational establishments (HEEs). Education in higher and secondary specialized educational institutions can be attributed to a specific type of activity, which is characterized by constant growth and complication of information, lack of time, increased requirements for solving problem situations, control rigidity and other factors [14-17].

2. Purposes, subjects and methods:

2.1. Purpose - basing on studying the structure and time course of depressive disorders of affective and neurotic registers in students of higher educational institutions, to develop a comprehensive pathopsychologically grounded system of their psychotherapy and psychoprophylaxis.

The object of study: depressive disorders of affective and neurotic registers in university students.

\subsection{Subjects \& Methods}

The research was carried out from 2010 to 2013 in four stages. In the first stage of the study, 200 patients with depressive disorders of the neurotic and affective registers were investigated under informed consent with observance of the principles of bioethics and deontology on the basis of Kharkiv City Psychoneurological Dispensary No.3 and the Students' Youth Center for Mental Health in Kharkiv City Student Hospital (79 patients with depressive disorders of the affective register (DDAR) and 121 patients with depressive disorders of the neurotic register (DDNR)). In the second stage, on the basis of analysis of clinical features of emotional disorders and psychological properties of students, we determined the targets of their psychotherapeutic influence. Patients of the study group (SG), along with treatment in accordance with the standards of medical care for this disease received standard treatment and participated in implementation of measures of the psychotherapeutic correction system, developed by the author; control group patients (CG) received only standard treatment.

At the third and fourth stages of the study, active and supportive psychotherapy of students with depressive disorders of various genesis and an assessment of its effectiveness was conducted.

In this work a set of research methods was used, which included anamnestic, socio- demographic, clinical-psychopathological, psychodiagnostic and mathematical-statistical methods.

The anamnestic method was used to identify the anamnestic factors in the development of depressive disorders in the affective or neurotic register; the peculiarities of personality development and education in the family were studied.

The socio-demographic method involved the study of characteristics such as distribution of patients by age, level of education, family status, social status, university profile and type of work.

Clinico-psychopathological method was based on generally accepted approaches to psychiatric examination by interviewing and observing. The survey was conducted using diagnostic and research criteria of ICD-10. the standard psychometric self-assessing Beck Depression Inventory was used to assess the time course of mental state during the treatment and catamnestic observation [18]. The clinicalpsychopathological method was supplemented by a survey using the individual card of examination of patients with depressive disorders proposed by us.

Moreover, psychometric study included the study of the severity of psychopathological symptoms using Hamilton Rating Scale for anxiety and depression (HDRS and HARS, 1960) [19] and Montgomery-Asberg Depression Rating Scale (MADRS, 1979). [20] Psychodiagnostic survey included the study of personal characteristics of students with the help of the Eysenck Personality Inventory (EPI) [21] and the diagnostic Buss-Durkee Inventory Questionnaire of Aggression (1957). [22]

Statistical data were processed using mathematical t-test method [23]. The method was to conduct a comparative study on the $\mathrm{t}$-criterion according to the traditional method for parametric statistics. Also, the data were processed using t-test to determine the probability of disagreement between the groups [23].

Conflict of interests. There is no conflict of interests.

\section{Results and discussion}

Various studies conducted by scientists in Canada and collected in "Teaching students with mental health disorders: resources for teachers" [24] have shown, that adolescents with depression are commonly found to have sustained sadness and tearfulness. They cry easily and the sadness seems out of proportion to the apparent source of sadness. They are difficult to console. This 
sadness can be quite frightening to young people with depression, who cannot seem to return to equilibrium easily and for whom the feelings seem overwhelming and endless. With younger ones this sadness more often takes the form of lethargy and listlessness. Unexplained irritation is a prominent symptom of depression in students of all ages. They are quarrelsome, disrespectful of authority, hostile and prone to sudden anger. There is increased shouting and screaming. Students are seen as agitated, which is demonstrated by the inability to sit still, excessive fidgeting, picking or pulling at hair, skin, clothing or other objects. Alternatively, there may be some psychomotor retardation - coordination is poor and the studen looks clumsy. Students with depression may withdraw from participation in different activities, have difficulty concentrating and making decisions. Loss of energy, easily and quick annoyance and hypersensitive to the comments and actions of others, sleep disturbances and substance abuse are very common to this contingent.

Another research [25] showed that the strongest population-level baseline predictors for major depressive disorder (MDD) in first-year college students were history of childhoodadolescent trauma, stressful experience in the past 12 months, parental psychopathology, and other 12-month mental disorder.

The results of the study of medical students show an increase in anxiety-depressive symptoms in fifth-year-students relative to the first one almost doubled. [26, 27]

Research results. Our clinical analysis showed that emotional disorders in patients of the study group were most often structured in the form of such manifestations of emotional disorders as: depressive disorders of the affective register, depressive episode in $52.8 \% \pm 5.6$ and recurrent depressive disorder in $36.1 \% \pm 5.4$ cases. In depressive disorders of the neurotic register, adjustment disorders were found in $55.6 \% \pm 4.5$ and prolonged depressive reaction in $35.8 \% \pm 4.4$ cases.

The results of the study showed that the number of students assigned to certain observation group depended on their gender and year of study. The depressive disorder of the affective and neurotic registers often affected females $(67.1 \%$ with DDAR and $60.3 \%$ with DDNR, at $p<0.05$ ). Depressive disorder of the affective register was more common among students of the fourth $(26.6 \%)$ and fifth $(59.5 \%)$ years of study. While depressive disorder of the neurotic register was significantly prevalent among first-year (43.8\%) and second-year $(38.8 \%)$ students (at $\mathrm{p}<0.01)$.

The time course of mental state of students throughout the course of study is characterized by a wave-like course. The greatest number of complaints of general character and symptoms in different psychic spheres was observed in the students of the first two years. Subsequently, they gradual declined and only in the senior years this indicator rose again. The results of our study showed that there were general patterns of the time course of mental state of students that did not depend on the profile of the university and the duration of the training, but only related to its periods (junior, middle and senior years). Probably, this fact can be explained by the effect of the adaptive mechanisms to the conditions of learning, which determine the number and combination of complaints and symptoms in different mental areas.

Thus, in depressive disorders of the neurotic register, deterioration of general well-being was first of all determined by a decrease in mental working capacity, quality of night sleep, presence of headaches $(51,2 \%)$, and somatovegetative disorders. Most students presented with inattention (91.7\%), fatigue $(90.0 \%)$, mental tiredness (69.4\%). Dissomnic symptoms were manifested in the form of violations of the duration and quality of night sleep, increased drowsiness, difficulty falling asleep, lack of vivacity after sleep $(92.6 \%)$.

Among various disorders of perception, hyperesthesia was most often found $(66.2 \%$ of students) against the background of intense learning activity. It, in turn, could be accompanied by emotional distraction, irritability $(87.6 \%)$.

In the structure of thought disorders, two main groups of symptoms were identified: disorders associated with learning activities, and negative thoughts about their own personality or relatives. The most frequent symptoms of the first group include the difficulty of understanding the contents of what was read or heard (54.5\% of students) and a decrease in wit (35.2\%). The second group of symptoms was represented primarily by concerns about health (71.2\%), disability and low value $(67.6 \%)$, thoughts about the problems in family and loved ones $(76.1 \%)$.

Emotional disorders were most often represented by a rapid change in mood $(100.0 \%$ of students), irritability (87.6\%), anxiety, feeling of inner tension $(75.2 \%)$, and a decline in the range of interests $(46.3 \%)$, indifference to one's condition and one's fate (31.6\%), coldness, and 
sometimes hostility to close ones (71.6\%). These symptoms were more common during the exam sessions, especially in junior students.

The incidence of effector-volitional disorders was as follows: isolation ( $83.2 \%$ of students), lack of activity (66.2\%), lethargy, inactivity $(61.3 \%)$, or increased activity with rapid fatigue $(69.4 \%)$, self-doubts $(85.8 \%)$. The presented symptoms also intensified at the end of the semester and often continued at the beginning of the vacation period.

Vegetative disorders, first of all, included vegetative-vascular impairments, including face reddening in excitement and rest states $(56.8 \%)$, increased blood pressure (46.3\%), tachycardia (79.3\%), and sweating (67.8\%), tremor of fingers and hands, especially under emotional stress $(62,7 \%)$.

In case of depressive disorders of the affective register, basing on the conducted research, it was established that there were common psychopathological features of endogenous depressions of adolescence. First, they included pronounced polymorphism of presentation with incompleteness, fragmentary, variability of psychopathological symptoms and fuzzy registration of the affective triad. The analysis showed that the features of depressive states in the patients under investigation and their peculiarities should be explained by the significant contribution of pubertal psychosocial factors in their formation. This leads to the development of cognitive, behavioral and somatovegetative disorders typical for adolescents, not only masking their depressive basis, but also complicating the correct interpretation of individual symptoms of the disease.

Thus, the detailed analysis of the structure of juvenile depressive states showed that only in $15.3 \%$ of patients the presentation approached the typical melancholy depression characteristic for mature patients, but still, differing from the latter by the lack of a harmoniously presented "classical" depressive triad.

In the structure of the depressive syndrome of affective register, first of all, attention is paid to the insignificant severity of the actual thymic component. As a rule, patients experienced a decline in vital tone, and the main plot of their experiences was the feeling of rapid "mental exhaustion", "inattention", "moral impotence", "moral indifference" (complaints of weakness in $89.9 \%$, fatigue in $91.1 \%$, apathy in $77.2 \%$, loss of ability to work in $74.7 \%$ of the examined). The manifestations of such ideational disorders usually prevailed over the typical signs of depressive syndrome. In addition, some patients expressed the idea of self-exclusion (94.9\%), inferiority, suicidal thoughts, accompanied by a predominance of vegetative and visceral crises, somaticautonomic disorders of the cardiovascular and respiratory system (fluctuations of blood pressure in $35.42 \%$, difficulty breathing in $40.5 \%$, rapid heartbeat in $11.4 \%$, increased sweating in $8.9 \%$ of the examined students). Youth depression was manifested by fussiness, accelerated speech, up to motor stimulation and agitation. At the same time, anxiety in $87.3 \%$ of patients was felt physically (in the chest, head), which allowed to talk about its vital nature. In addition, some of the patients observed daily oscillations with the most pronounced anxiety in the second half of the day. Vital disorders in students were often expressed by decreased "vital tone", "lack of energy" or a sense of emotional discomfort. In a number of cases this was evidenced by the ideas of inferiority, gloomy assessment of the future, domination of memories of sad and unpleasant events (46.8\%), pessimistic reflections on the lack of purpose of human existence, eventually formulated in a system of metaphysical, overvalued depressed world outlook.

It is necessary to pay special attention to the features of ideational disorders in patients with juvenile depressions of the affective register occupying the dominant position in the clinical picture in most of them. These disorders of different qualitative structure were found in almost all patients. Along with this complex of symptoms, patients suffered from impaired memory and attention (in 63.3\%), which also indicated retardation of intellectual processes. Clinical and psychopathological investigation allowed to determine the prevalence and syndromological structure of mental disorders in the examined patients of both groups. Thus, in patients with DDAR, the presence of astheniadepressive syndrome was detected in $83.5 \%$, anxiety-depressive in $87.3 \%$, and somatic and vegetative syndrome in $27.8 \%$ of the subjects. The presence of asthenia-depressive syndrome in $97.5 \%$ of cases, depression-hypochondria syndrome in $60.3 \%$ of cases, and somatic and vegetative syndrome in $52.1 \%$ of cases was observed among students with DDNR.

The conducted study showed that on the Hamilton scale, in the majority of patients with DDAR in SG1, moderate anxiety prevailed $(20.6 \pm 2.3$ in $37.5 \%$ at $p<0.01)$ and depression of moderate and severe degree $(21.1 \pm 2.2$ in $37.5 \%$ and $32.4 \pm 1.9$ in $50.0 \%$ respectively at $\mathrm{p}<0.01$ ). 
There were no reliable differences in indicators in SG1 with indicators in CG1.

In the majority of the subjects from the SG 2, patients with DDNR, reliably presented with manifestations of anxiety $(15.5 \pm 1.1$ in $41.98 \%$ and $20.7 \pm 2.2$ in $28.4 \%$ surveyed at $\mathrm{p}<0.01$ ), an indicator of mild and moderate anxiety and depression $(21.7 \pm 2.3$ in $40.7 \%$, a credible predominance of moderate depression at $\mathrm{p}<0.01$ ). There were no reliable differences between indicators in SG2 and indicators in CG2.

Assessment by the Montgomery-Asberg Depression Rating Scale of students with DDAR in $\mathrm{SG} 1$ showed a significant prevalence of depressive episode: minor $-20.7 \pm 2.8$ in $22.9 \%$, moderate $-28.1 \pm 1.3$ in $27.1 \%$ and major $36.7 \pm 1.02$ in $39.6 \%$ at $p<0.01$. Students with DBNR had a significant prevalence of minor $(21.4 \pm 1.9$ in $56.8 \%)$ and moderate $(27.9 \pm 1.4$ in $22.2 \%$ ) depressive episodes in SG2 at $\mathrm{p}<0.01$. There were no reliable differences between indicators in SG1 and indicators in CG1 and SG2 with CG2.

According to Beck Depression Inventory, most students with DDAR noted the presence of moderate depression (25.4 \pm 2.3 in $37.5 \%)$ and severe (34.7 \pm 1.9 in $31.25 \%$ ) depression in SG1 at $\mathrm{p}<0.01$. Most students with DDNR noted the presence of mild $(12.1 \pm 1.5$ in $32.1 \%)$ and moderate (17.8 \pm 1.1 in $27.2 \%$ ) depression in SG2 at $\mathrm{p}<0.01$. There were no reliable differences between the indicators in SG1 with indicators in CG1 and SG2 with CG2.

According to different researches [28], depressive personality and some traits, particularly neuroticism/negative emotionality, predict the subsequent onset of depressive disorders. However, it is unclear at this point whether they are best conceptualized as precursors or predispositions, as it is difficult to differentiate between these models, and there is evidence supporting both accounts. In either case, there is growing evidence that temperamental risk factors are evident at an early age, suggesting a promising approach to identifying young children at risk for depression.

In our work we found, that the general assessment of indicators on the scales of neuroticism and extraversion / introversion of the Eysenck Personality Inventory allowed to conduct an analysis of the types of temperament in the students under investigation. Relatively predominant type of temperament in the group of patients with depressive disorders of the neurotic register was choleric (in $42.1 \%$ ), sanguine type was found less frequently, namely in $9.9 \%$ cases, than phlegmatic (in $32.2 \%$ ) and melancholic (in 15.7\%) due to high rates of extraversion in most of the students under study.

Most students with depressive disorders of the affective register predominantly had phlegmatic type of temperament (in $59.5 \%$ ), the least common was sanguine (in $6.37 \%$ surveyed) type due to high rates of introversion.

Literature review showed that the correlation between aggression and depression is not important enough to become a powerful predictor of either close or remote event. This means that, despite the existence of a specific association, it is too weak and, in fact, in the literature it appears as a variable association [29]. The fact that the correlation between anger and depression is weaker than the correlation with aggression is something that appears in the literature repeatedly [30]. It becomes apparent that for the purpose of emotional interaction, anger trait represents a more important role than the anger state which we can find consistently in previous research about emotions in adolescence [31]. This is perfectly coherent given that anger state is crucial and it is not permanent and therefore it has to vary much more easily than anger trait $[31,32]$.

To sum up the literature review, in the models it becomes apparent that instability predicts depression and anger, but not aggression, the latter only appears if instability is associated to anger. The prediction of emotions of the internalized kind can predict those internalized directly, but also the indirectly internalized if we take anger into account. It is obvious that all this has consequences in the preparation of all programs for the establishment of emotional control over adolescents, as it is necessary to take into account as the direct aim not only the control over externalized emotions such as anger, but also over internalized emotions such as emotional instability [33].

When analyzing the indicators by the BussDurkee Inventory questionnaire of aggression in our research, particular attention was paid to the scales of physical aggression and irritability. They together form the index of aggression (both direct and motivational), and also on the scale of images and suspicions, which are components of the index of hostility.

The Buss-Durkee Inventory questionnaire showed links of indicators of aggression and hostility with violations of socio-psychological functioning in the sphere of interpersonal duties, 
communication, and sexual relationships. A number of patients in this group in the premorbid stage were found to have active, extrapunitive forms of aggression and hostility (in the form of suspicion), as well as intrapunitive forms demonstrated as suicidal tendencies and selfdestructive actions.

High rates of hostility and anger were informative indications, which reliably indicated depressive episodes already existing in the history and the belonging of the group under study to the "high risk of becoming depressed". These students also demonstrated special coping strategies in the form of a tendency to "blame themselves in negative events", "blame others", and "seek social support". The combination of these factors intense anger, high hostility, a tendency to accusations to their own address and the address of other people, the influx of thoughts of negative content, create "interpersonal storms", impede the reception of the desired support and dramatically increase the likelihood of manifestation of depression.

Based on the obtained results, we have substantiated and developed an algorithm for providing psychotherapy for students with depressive disorders of affective and neurotic registers.

For the solution of the tasks, drug (new generation antidepressants - selective serotonin reuptake inhibitors (SSRI)) and non-drug (Cognitive Behavioral Therapy (CBT) in the modification of A. Beck) methods were used. The control group simultaneously received standard drug therapy (antidepressants).

Psychotherapy was carried out simultaneously with administration of drugs and was conducted in three stages.

Task of the first (didactic) stage: awareness of the mechanisms of disease development and therapy.

Task of the second (actually cognitive) stage: detection of maladaptive "automatic" thoughts that support disappointment, depression, negative selfperception.

Task of the third (behavioral) stage: a special strategy that teaches self-esteem and forms positive motivation.

Psychotherapeutic techniques in students in study groups had different emphasis on intervention. So, CBT in DDAR was aimed at eliminating the motivational, behavioral and physical symptoms of depression. The patient was helped to restore the ability to control the situation, cope with it, overcome the feeling of incompetence and helplessness, overestimate the usual life difficulties that were perceived as unbearable, overcome fatigue and inertia. An important role in the recovery was played by the refutation of negative expectations and demonstration of motor ability.

CBT in DDNR was aimed at understanding the role of stress that arose in the development of a patient's illness. The necessary stage of work was the change in the attitude of the patient to the traumatic (stress) situation and its adoption as part of life experience. An important part was the reassessment of their own role in a traumatic situation, the assumption of a certain share of responsibility with the formation of an active position in overcoming the current circumstances.

After the period of formation of compliant relations, 14-16 sessions of CBT were conducted within two months. Students with pronounced somato-vegetative components were trained in the technique of autotraining (AT) in the modification of B.V. Mykhaylov [34].

In summary, the study of the effectiveness of the conducted program of psychotherapy in the study groups, compared with the control groups, was assessed by objective (MontgomeryAsberg Depression Rating Scale (MADRS)), and subjective criteria (Beck Depression Inventory).

The effectiveness of the treatment in RG1 was $67.23 \%$.

The effectiveness of the treatment in RG2 was $88.58 \%$.

Thus, the application of our model of psychotherapy, built on the integrative principle, has shown its high efficiency. Owing to the integrated approach in the treatment of depression disorder among university students after the completion of the course of psychotherapeutic activities, there was an increase in the level of motivation and interest in learning, as well as further employment. Students found improvement in the cognitive field, which was manifested by increased attention concentration, memory improvement and resistance to stressors. The effectiveness of the proposed model was $77.9 \%$.

\section{Conclusions:}

1. Diagnosis of depressive disorders should involve psycho-diagnostic data of psychoemotional state analysis and take into account syndromological structure of depressive disorders of the affective or neurotic register to normalize the state of the emotional sphere in students with depressive disorders of both registers.

2. The program of psychotherapy should be built on an integrative principle, combining a 
systematically stratified step-by-step approach and taking into account the individual-typological features of patients.

3. This three-stage psychotherapy program should be used in practice (awareness of the mechanisms of disease development and therapy; identification of maladaptive "automatic" thoughts, self-esteem training and the formation of positive motivation; as well as auto-training techniques) for students of higher educational institutions who suffer from depressive disorders due to its high effectiveness in primary medical care.

4. In order to implement the psychotherapy system, it is necessary to involve psychiatrists and psychotherapists in the specialized unit of the institutions providing primary medical care.

\section{References:}

1. Lavrentjeva, N. A. (2008) Vujavlenie urovnya nevrotizacii i narushenija adaptacii k uchebnomy process cnudentov Voronezhskoj gosudarstvennoj medicinskoj akademii [Identification of the level of neuroticism and violation of adaptation to the educational process of students of the Voronezh State Medical Academy]. Problemu zdorovjesberezhenia shkolnikov i studentov. Novue naychnue tendencii v medicine i farmacii, pp. 257-59.

2. Maruta N., Semikina O., Maluta L. (2011) Kognituvno-bihevioralna terapia pru likyvanni depresuvnuh poryshenj [Cognitive-behavioral therapy in the treatment of depressive disorders]. Tavricheskij zhurnal psihiatrii, №2 (52), pp. 32-33.

3. Hawton, K., Bergen H., Mahadevan Su (2012). Suicide and deliberate self-harm in Oxford University students over a 30-year period. Social Psychiatry and Psychiatric Epidemiology, Vol. 47, № 1, pp. 43-51.

4. Mykhaylov B. (2006). Sovremennoe sostojanie problem depressivnuh rasstrojstv [The current state of the problem of depressive disorders]. Problemu meduchnoi nayku ta osvitu, №2, pp. 65-69.

5. Pidkorutov V., Serikov O., Djachenko L., Sazonov S., Skrunnuk O. (2009). Faktoru, sho v najbilshomy stypeni vpluvajytj na pokaznuku vrahovanoi zahvoryvanosti ta poshurenosti psuhichnuh rozladiv sered naselennya Ukrainu [Factors that have the greatest impact on the indicators of the estimated incidence and prevalence of mental disorders among the Ukrainian population]. Ukrainskij visnuk psuhonevrologii, Vol. 17, №2 (59), pp. 51-57.

6. Hobzej M., Voloshin P., Maruta N., Zinchenko O., Petrichenko O., Djachenko L. (2012). Stan psuhichnogo zdorovja naselelnnya ta perspektuvu rozvutky psuhiatruchnoi dopomogu v Ukraini [The state of mental health and the prospects for the development of psychiatric care in Ukraine]. Ukrainskij visnuk psuhonevrologii, Vol. 20, №. 3 (72), pp. 13-18.

7. Eskin M., Voracek M., Stieger St. (2011) A cross-cultural investigation of suicidal behavior and attitudes in Austrian and Turkish medical students. Social Psychiatry and Psychiatric Epidemiology, Vol. 46, № 9, pp. 813-823.

8. Mishiev V., Pyshkareva T., Kyshnir J., Blazhevich J., Ershova E., Osadchaja G. (2011). Depressivnue rasstrojstva $\mathrm{v}$ stryktyre sindroma hronicheskoj ystalosti y zhenchin reprodyktivnogo vozrasta: klinika I principu terapii [Depressive disorders in the structure of chronic fatigue syndrome in women of reproductive age: clinic and treatment principles.]. Perinatologia ta pediatria, № 4, pp. 111-113.

9. Hobzej M., Voloshin P., Maruta N. (2010). Socialno-orientovana psuhiatruchna dopomoga v Ukraini: problemu ta rishennya [Socially-oriented psychiatric care in Ukraine: problems and solutions]. Ukrainskij visnuk psuhonevrologii, Vol. 18, №3 (64), pp. 10-14.

10. Zhdanova M., Kolyakova O., Zinchenko O., Maruta N. (2009). Stan i perspektuvu rozvutky psuhiatruchnoi slyzhbu v Ukraini [Status and prospects of development of psychiatric service in Ukraine]. Ukrainskij visnuk psuhonevrologii, Vol. 17, №. 2 (59), pp. 6-9.

11. Jyrjeva L. (2004). Rasprostranennostj I vurazhennostj sindroma vugoranija y vrachej-psihiatrov v Ukraine [The prevalence and severity of burnout syndrome among psychiatrists in Ukraine]. Zhyrnal psihiatrii I medicinskoj psihologii, №4, pp. 184-185.

12. Napreenko O. (2002). Depresii ta truvoga v zagaljnij meduchnij praktuci (socialjni, diagnostuchni ta likyvaljno-profilaktuchni aspektu) [Depression and anxiety in general medical practice (social, diagnostic and therapeutic and preventive aspects)]. Visnuk psuhiatrii ta psuhofarmakologii, №1, pp. 7-12.

13. Mishuev V. (2004). Sychasni depresuvni rozladu. Kerivnuctvo dlya likariv [Modern depressive disorders. Guide for doctors]. Lviv, $208 \mathrm{p}$.

14. Gavenko V., Sinajko V., Sokolova I. (2001). Organizacija I oput rabotu psihologicheskoj slyzhbu $\mathrm{v}$ vyze [Organization and experience of the psychological service at the university] Materialu Plenymy yaykovo-praktuchnogo tovarustva nevrologiv, psuhiatriv ta narkologiv Ukrainu, Ternopilj: Ukrmedkniga, pp. $40-44$. 
15. Kozhuna A., Gajchyk L., Zelenskaja E. (2011). Narushenie adaptacii stydentov mladshih kursov k ychebnoj dejateljnosti v vyze III-IV urovnej akkreditacii [Violation of the adaptation of undergraduate students to educational activities at a higher educational institution of III-IV accreditation levels]. Meduchna psuhologija, № 1, pp. 37-39.

16. Korostij V. (2011). Kognitivnaja psihoterapija v lechenii trevozhnuh i depressivnuh rasstrojstv y moloduh lic s psihosomaticheskimi zabolevanijami [Cognitive psychotherapy in the treatment of anxiety and depressive disorders in young people with psychosomatic diseases]. Medicinskaja psihologija, № 2, pp. $76-80$.

17. Bayram N., Bilgel N. (2008). The prevalence and socio-demographic correlations of depression, anxiety and stress among a group of university students. Social Psychiatry and Psychiatric Epidemiology. Vol. 43, № 8, pp. 667-672.

18. Beck A. T. et al. (1961). An Inventory for Measuring Depression. Archives of general psychiatry. Vol. 4. №. 6. pp. 561-571.

19. Hamilton M. (1960). A rating scale for depression. J Neural Neurosurg Psychiatry. Vol. 23, pp. $56-62$.

20. Montgomery S.A., Asberg M. (1979). "A new depression scale designed to be sensitive to change". British Journal of Psychiatry. 134 (4). pp. 382-89.

21. Eysenck H.J., Eysenck S.B.G. (1968) Manual of the Eysenck Personality Inventory (EPI). London: University of London Press.

22. Buss A. H., Durkee A. (1957). An inventory for assessing different kinds of hostility. Journal of Consulting Psychology. Vol 21. pp. 343-348.

23. Gybler E. (1978). Vuchisliteljnue metodu analiza I raspoznavanija patologicheskih processov [Computational methods of analysis and recognition of pathological processes]. Leningrad: Medicina, Leningradskoe otdelenie, $296 \mathrm{p}$.

24. Teaching students with mental health disorders: resources for teachers. Depression. (2001) National Library of Canada Cataloguing in Publication. Vol. 2. 48 P.

25. Ebert D.D., Buntrock C., Mortier P., Auerbach R., Weisel K.K., Kessler R.C., .... Bruffaerts R. (2019). Prediction of major depressive disorder onset in college students. Pub.Med. Depress Anxiety. 36(4). pp. 294-304. https://www.ncbi.nlm.nih.gov/pmc/articles/PMC6519292/

26. Strizhev V. A., Bojko E. O., Lozhnikova L. E., Zajceva O. G. (2016). Trevozhno-depressivnue rasstrojstva $\mathrm{v}$ medicinskoj studencheskoj srede. [Anxiety-depressive disorders in the medical student environment]. Kubanskij naychnuj medicinskij vestnik. № 2 (157). C. 126-131.

27. Tumutova E. Ch., Dyrinova A. B., Strambovskaja N. N. (2008). Trevozhno-depressivnue rasstrojstva y stydentov medicinskogo faculteta BGY. [Anxiety-depressive disorders in medical students of BSU]. Bulletenj VSNC SO RAMN. №3 (61). pp. 147-148.

28. Klein N. D., Kotov R., Bufferd J. S. (2011). Personality and Depression: Explanatory Models and Review of the Evidence. Annu Rev Clin Psychol. Vol. 7. pp. 269-295.

29. Kosterman R., Hawkins J. D., Mason W. A., Herrenkohl T. I., Lengua L. J., McCauley E. J. (2009) Assessment of Behavior Problems in Childhood and Adolescence as Predictors of Early Adult Depression. Psychopathol Behav Assess. Vol. 32(1). pp.118-127.

30. Ingoldsby E. M., Kohl G. O., McMahon R. J., Lengua L. (2006). Conduct problems, depressive symptomatology and their co-occurring presentation in childhood as predictors of adjustment in early adolescence. J Abnorm Child Psychol. Vol. 34. pp. 603-621.

31. Lonigro A., Schneider B. H., Laghi F., Baiocco R., Pallini S., Brunner T. (2015). Is cyberbullying related to trait or state anger? Child Psychiatry Hum Dev. Vol. 46. pp. 445-454.

32. Quinn C. A., Rollock D., Vrana S. R. (2014). A test of Spielberger's state-trait theory of anger with adolescents. Five hypotheses. Emotion. Vol. 14. pp. 74-84.

33. Llorca A., Malonda E., Samper P. (2016). The role of emotions in depression and aggression. Med Oral Patol Oral Cir Bucal. Vol. 21(5). pp. 559-564.

34. Mykhaylov B. (2012). Sovremennaja modifikacija metodov autigennoj trenirovki [Modern modification of autogenic training methods]. Materialy nauchno-prakticheskij konferencii s mezdunarodnum ychastiem, posvyashennoj 150-letijy kyrorta "Berezovskije mineralnue vodu" I 50-letijy kafedru psihoterapii HMAPO, Vol. 2, pp. 157-160. 